\title{
EU climate law sans frontières: The extension of the 2030 Framework to the Energy Community contracting parties
}

\author{
Stephen Minas 10
}

Correspondence

Email: stephen.minas@kcl.ac.uk

\begin{abstract}
As challenging as meeting the 2030 climate and energy targets will be for the European Union (EU), it is the decision to extend the 2030 Framework to the contracting parties of the Energy Community (EnC) which will arguably require a truly Herculean effort. In 2018, the contracting parties agreed to adapt the revised Energy Efficiency and Renewable Energy Directives, and the Energy Union Governance Regulation. However, the EnC parties face significant obstacles, while the Energy Community has limited compliance mechanisms. This article examines the Energy Community as a hybrid legal space in which the European Commission, EnC Secretariat and contracting parties co-create legal order. It investigates major challenges to the extension of the 2030 Framework to the Energy Community, including the EnC's structure and composition, weaknesses in national implementation and a limited dispute resolution regime. The article also reflects on the role of law in the external dimension of EU climate policy.
\end{abstract}

\section{1 | INTRODUCTION}

The adoption and subsequent strengthening of the 2030 Climate and Energy Policy Framework were milestones in the development of the European Union's (EU) approach to climate policy. The legislation to implement the 2030 Framework is important to the achievement of the EU's nationally determined contribution (NDC) under the Paris Agreement. Nevertheless, the EU is responsible for a declining share of global greenhouse gas emissions, currently estimated at around 9 percent. $^{1}$ This indicates that the EU's domestic emission abatement and turn to cleaner energy, while important and necessary, can have only limited impact on the global trajectory. Of at least equal importance is the EU's ability to work with other

${ }^{1}$ Commission (EU), 'The European Union Continues to Lead Global Fight against Climate Change' (11 September 2019) <https://ec.europa.eu/clima/news/european-union-conti nues-lead-global-fight-against-climate-change_en>. Excluding the United Kingdom's emissions, this figure would be even lower. countries - especially those whose emissions have yet to peak - to strengthen their climate mitigation outcomes. Recognizing this, EU diplomacy and development assistance increasingly target the achievement of climate mitigation, as well as adaptation, beyond the EU's borders.

For these reasons, the study of the 2030 Framework's domestic operation should be complemented by an investigation of its external dimension. In January 2020, the Council of the EU concluded that '[e]fforts beyond the EU must urgently be scaled up ... The European Union needs to urge third countries to intensify their efforts alongside the European Union.' ${ }^{2}$ Can the 2030 Framework, in addition to structuring EU and Member State climate mitigation, contribute to this objective to strengthen action in third countries? This article

2European Council, 'Council Conclusions on Climate Diplomacy', 5033/20 (20 January 2020) paras 3,5 .

This is an open access article under the terms of the Creative Commons Attribution License, which permits use, distribution and reproduction in any medium, provided the original work is properly cited.

(c) 2020 The Authors. Review of European, Comparative \& International Environmental Law published by John Wiley \& Sons Ltd 
examines the external application of the 2030 Framework to the Energy Community (EnC) contracting parties, located in Eastern Europe and the Caucasus. This study is novel because it deals with the external promotion of the 2030 objectives not through diplomacy or development assistance, but rather through a process to extend a hybridized form of EU law to third countries. It is also novel because it details the current struggle to incorporate laws focused on climate mitigation into the legal order of the Energy Community.

This article argues that the extension of the 2030 Framework in EnC contracting parties is a key test of the extension of the 2030 Framework to third countries based on EU legislation. ${ }^{3}$ Most contracting parties have significantly lower levels of economic development and less advanced transitions to sustainable energy, compared to the EU average. Therefore, their ability and willingness to adapt and implement the 2030 Framework is a test of the degree to which the EU's legislative approach to achieving the Paris Agreement's goals can be followed by countries with different national circumstances.

The article applies a theoretical approach of legal pluralism to the Energy Community's reception of the 2030 Framework. The legal pluralist perspective is useful for foregrounding the interaction of multiple sources of norms in the bespoke EnC setting. The Energy Community is assessed to be a hybrid legal space, in which the outcomes of normative interaction - among EU law, EnC frameworks and contracting party legal systems - are contingent and contested. As will be seen, this framing can be utilized to make sense of current challenges of implementation and to inform the future development of the Energy Community.

The article is structured as follows. Section 2 provides a brief overview of the Energy Community. Section 3 introduces the elements of the 2030 Framework that the Energy Community has decided to adopt into its law, and discusses the ongoing process for achieving this. Section 4 considers key challenges to implementing the 2030 Framework in the Energy Community by (Section 4.1) reflecting on the Energy Community as a hybrid legal space, quite different to the legal space of the EU, (Section 4.2) focusing on the troubled record of national implementation of the acquis by Contracting Parties and (Section 4.3) analysing the challenge of enforcement in a legal order that lacks compulsory judicial or arbitral dispute resolution, but which has begun to utilize mediation. Section 5 discusses the findings regarding challenges of implementation. Section 6 concludes that the successful extension of the 2030 Framework to the Energy Community depends on narrowing the gaps between the EU and EnC legal orders, implementation with sensitivity to national circumstances and legal culture, and greater investment in robust dispute resolution. It further concludes that the EnC case suggests that law has an important role to play in the external dimension of the 2030 Framework, alongside diplomacy and development assistance. However, the EnC case also exposes the difficulties inherent in extending EU law beyond EU borders, and highlights the need for the EU to address the complexities of constructing and navigating hybrid legal spaces, rather than assuming a simpler model of 'legal transplantation'.

${ }^{3}$ For a recent summary of what constitutes EU climate law, see M Peeters, 'EU Climate Law: Largely Uncharted Legal Territory' (2019) 9 Climate Law 137.

\section{2 | THE ENERGY COMMUNITY}

The creation of the Energy Community was an attempt to deal with the legacies, and explore the opportunities, of the collapse of the Eastern Bloc of Communist States in Central and Eastern Europe. By the early 2000s, the post-Communist States of Central and Eastern Europe had largely transitioned to democracy, and in 2004 eight post-Communist States joined the EU. However, the transitions of many former Eastern Bloc States to a social market economy were difficult. Their energy sectors were typically fossilfuel-based, polluting, largely State-owned, dominated by monopolies or oligopolies, closed to foreign participation and constrained in attracting external investment. In several Western Balkan jurisdictions, the recent wars had resulted in significant damage to electricity infrastructure. ${ }^{4}$

On the eve of the Energy Community's creation, there were significant divergences concerning electricity market liberalization $^{5}$ between EU Member States and the States that would become EnC contracting parties. ${ }^{6}$ For example, in 2004, almost all EU Member States had introduced some form of unbundling for transmission operators. By contrast, none of the soon-to-be EnC contracting parties Bosnia and Herzegovina (BiH), Croatia, North Macedonia and Serbia and Montenegro (as it then was) had unbundled transmission. ${ }^{7}$ There was a similar divergence in the area of retail competition. Future EnC contracting parties Albania, $\mathrm{BiH}$, Bulgaria, North Macedonia and Serbia and Montenegro each had zero electricity suppliers independent of the distribution system operator, a lack of competition present in the EU only in new Member States Cyprus, Czechia and Malta. ${ }^{8}$ Moreover, Albania, Bulgaria and Serbia and Montenegro each reported zero market share for foreign-owned suppliers, again in contrast to the vast majority of EU Member States. ${ }^{9}$

To address these challenges, the EU proposed an integrated energy market for Southeast Europe ${ }^{10}$ and, subsequently, formation of an Energy Community encompassing both the EU and non-EU

${ }^{4}$ E Hooper and A Medvedev, 'Electrifying Integration: Electricity Production and the South East Europe Regional Energy Market' (2009) 17 Utilities Policy 24.

${ }^{5}$ Market liberalization includes such changes as unbundling of generation, transmission, distribution and retail, the introduction of wholesale and retail competition with access for new market participants, independent regulators, third-party network access, opening to and infrastructure for cross-border trade, and privatization. T Jamasb and $M$ Pollitt, 'Electricity Market Reform in the European Union: Review of Progress toward Liberalization \& Integration' (2005) 26 The Energy Journal 11, 13ff. For a broader discussion of energy market liberalization, encompassing electricity, oil, upstream and downstream gas and coal, see M Pollitt, 'The Role of Policy in Energy Transitions: Lessons from the Energy Liberalisation Era' (2012) 50 Energy Policy 128.

${ }^{6}$ This is not to imply that market liberalization has been successfully realized in the EU, but rather to indicate the significantly greater challenges of market liberalization in EnC contracting parties vis-à-vis the EU. For a discussion of liberalization within the EU, see K Talus, EU Energy Law and Policy (Oxford University Press 2013) 289ff.

${ }^{7}$ Commission (EU) 'Technical Annexes to the Annual Report on the Implementation of the Gas and Electricity Internal Market' (Staff Working Document) SEC(2004) 1720, 5 January 2005, 9-10

${ }^{8}$ ibid 23-24.

${ }^{9}$ ibid.

${ }^{10} \mathrm{R}$ Karova, 'Regional Electricity Markets in Europe: Focus on the Energy Community' (2011) 19 Utilities Policy 80. 
Member States (the latter known as EnC contracting parties) within a 'single regulatory space'11 for energy. Interestingly, the European Commission described the process on energy cooperation which culminated in the Energy Community as 'stronger than the [pre-Lisbon Treaty] EU acquis in that it substantially goes beyond the acquis in pooling sovereignty in this strategic sector.. ${ }^{12}$ The Energy Community has been described as a mechanism to draw post-Socialist States into 'EU membership-lite arrangements', as a 'less maximalist' way of achieving EU energy security. ${ }^{13}$

The Treaty Establishing the Energy Community was adopted in 2005 and entered into force in 2006. The original contracting parties were Albania, Bulgaria, BiH, Croatia, Kosovo, ${ }^{14}$ Montenegro, North Macedonia, Romania and Serbia. As Bulgaria and Romania joined the EU in 2007, followed by Croatia in 2013, these States ceased to be EnC contracting parties. Moldova and Ukraine acceded to the EnC Treaty in 2010, followed by Georgia in 2016 . The parties to the EnC Treaty are the EU and the nine contracting parties.

The main mechanism for integrating EnC contracting parties into the common energy market is harmonization of energy law and regulation, through the extension of parts of the EU acquis into the laws of the EnC contracting parties. Although an ongoing focus of the Energy Community has been the liberalization of post-socialist energy markets, Energy Community law also addresses environmental protection and cleaner energy.

The EU's 2030 Climate and Energy Policy Framework is a milestone in the uncertain transformation of the Energy Community into a group of countries that will follow the EU's transition to climate-neutral energy. The decision of the Energy Community's Ministerial Council to adopt elements of the Clean Energy Package of legislation which address implementation of the 2030 Framework, including the Energy Union Governance Regulation and the recast Renewable Energy and Energy Efficiency Directives, into its own law, puts the Energy Community on a pathway to convergence with the EU - at least on paper. As will be seen, however, there are major obstacles to effective implementation.

\section{3 | INTRODUCING THE 2030 FRAMEWORK INTO ENERGY COMMUNITY LAW}

The Energy Community began to add regulation regarding climate change to its acquis with the Ministerial Council's 2016 Recommendation on preparing to implement the greenhouse gas

\footnotetext{
${ }^{11}$ Energy Community Treaty (adopted 1 October 2005, entered into force 1 July 2006) <https://energy-community.org/legal/treaty.html> (EnC Treaty) art 1(b).

${ }^{12}$ Commission (EU) (n 7) 57.

${ }^{13} \mathrm{R}$ Leal-Arcas, A Filis and ES Abu Gosh, International Energy Governance: Selected Legal Issues (Edward Elgar 2014) 336

${ }^{14}$ This designation is without prejudice to positions on status, and is in line with UNSC 'Resolution 1244' UN Doc S/RES/1244 (10 June 1999); and Accordance with International Law of the Unilateral Declaration of Independence in Respect of Kosovo, Advisory Opinion [2010] ICJ Rep 403.
}

emissions Monitoring Mechanism Regulation. ${ }^{15}$ The 2030 Framework $^{16}$ sets a fundamental challenge for the Energy Community. If it did not adopt the 2030 Framework into its acquis, the Energy Community would be left implementing an earlier and superseded iteration of EU energy law. EU law and EnC law would sharply diverge, and the purpose of achieving integration with the EU energy market would be frustrated. Facing this challenge, a June 2017 meeting of the contracting parties agreed to establish an Energy and Climate Committee to 'facilitate the development of climate policy and the transposition of related legislation into national legislation and support its effective implementation and to design 2030 targets for the Energy Community Contracting Parties'. ${ }^{17}$ In December 2017, the EnC Ministerial Council adopted a recommendation calling on contracting parties to begin preparing for the adoption of national energy and climate plans (NECPs), which the Ministerial Council noted would 'support the attainment of the longterm energy and climate policy objectives, reduce the administrative burden and enhance transparency while promoting investor certainty in the region'. ${ }^{18}$ The recommendation, which is not legally binding, states that NECPs should include objectives, policies and measures for each of the five dimensions of the Energy Union. ${ }^{19}$ The EnC Secretariat is tasked to assist contracting parties with the preparation of NECPs. ${ }^{20}$ The recommendation envisages that parties will report to the Secretariat on NECP implementation every two years, 'and where appropriate on an annual basis', and that the Secretariat will in turn report to the Ministerial Council every two years. ${ }^{21}$ Following the Ministerial Council's recommendation, in June 2018 the EnC Secretariat released guidelines on the development of NECPs, targeting the end of 2020 for the finalization of national plans. $^{22}$

Following work in the Energy and Climate Committee on an 'EUconvergent approach' to setting 2030 targets, the Energy Community established an Energy and Climate Technical Working Group, which meets regularly to lay the technical groundwork for contracting

\footnotetext{
${ }^{15}$ Ministerial Council Recommendation 2016/02/MC-EnC on preparing for the implementation of Regulation (EU) 525/2013 on a mechanism for monitoring and reporting greenhouse gas emissions.

${ }^{16}$ For an overview of the framework, see K Kulovesi and S Oberthür, 'The European Union's Climate and Energy Policy Framework for 2030: Incremental Change toward Radical Transformation?' (2020) 29 Review of European, Comparative and International Environmental Law 151.

${ }^{17}$ Energy Community Secretariat, 'Energy Community Climate Action Group Agrees on Pathway to Meet Climate Change Challenges' (2017) <www.energy-community.org/ news/Energy-Community-News/2017/09/05.html>; see further S Minas, 'Towards the East: The Energy Community and the Extension of EU Climate Governance' in S Minas and V Ntousas (eds), EU Climate Diplomacy: Politics, Law and Negotiations (Routledge 2018) $86,91-93$.

${ }^{18}$ Recommendation of the Ministerial Council of the Energy Community 2018/1/ MC-EnG on preparing for the development of integrated national energy and climate plans by the Contracting Parties of the Energy Community, preamble.

${ }^{19}$ ibid art 1(3).

${ }^{20}$ ibid art $1(7)$

${ }^{21}$ ibid art 4.

${ }^{22}$ Energy Community Secretariat, 'Policy Guidelines by the Energy Community Secretariat on the Development of National Energy and Climate Plans under Recommendation 2018/01/MC-EnC', PG 03/2018 (June 2018).
} 
party decisions on 2030 targets and NECPs. ${ }^{23}$ In November 2018 , the Ministerial Council adopted General Policy Guidelines on the 2030 targets. ${ }^{24}$ The Guidelines provide for three distinct targets, for energy efficiency, energy from renewables and emission reductions. The 2030 targets are to be incorporated into EnC law through adaptation of the Energy Efficiency Directive, the Renewable Energy Directive and the Governance Regulation. November 2019 was set as the deadline to approve adapted versions of these acts, ${ }^{25}$ but this deadline was not met. Contracting parties were to submit their draft NECPs to the Secretariat by March $2020^{26}$ and submit finalized plans by October 2020, taking into account Secretariat opinions and other feedback. $^{27}$ In September 2019, the EnC Permanent High Level Group noted that '[s]ome' Contracting Parties 'expressed the need for more time to establish robust 2030 targets'. ${ }^{28}$ At the Permanent High Level Group's subsequent meeting in December 2019, parties agreed that the EnC climate targets 'will be a sum of binding national targets adopted by the Ministerial Council'. ${ }^{29}$ This marks a divergence from the EU framework in which 2030 targets are set at the Union level. Finally, at the troubled Ministerial Council of December $2019,{ }^{30}$ the European Commission announced that it would 'propose the 2030 targets for the Energy Community and its Contracting Parties in the first half of 2021 alongside the adoption of the relevant legislative package'. ${ }^{31}$

These measures have set the direction towards acceptance of climate obligations within the EnC, designation of 2030 targets and adoption of the related Governance Regulation within the Energy Community, albeit with significant delays. However, the different conditions in the Energy Community mean that further progress in this direction is far from assured. As the EnC Secretariat's Director and Deputy Director have observed:

[T]he European Union is currently taking a bold step inspired by the Paris Agreement. Instead of a logic based on obligations and their enforcement, the future of our energy sectors will be decided in a spirit of self-responsibility and cooperation. This new governance seems appropriate to tackle the challenges of the second energy transition in the European Union. Whether and how it

\footnotetext{
${ }^{23}$ Energy Community, 'Energy and Climate Technical Working Group - 1st Meeting, Vienna, 14 June 2018, Minutes' 1.

${ }^{24}$ Energy Community, 'General Policy Guidelines on the 2030 Targets for the Contracting Parties of the Energy Community' Annex 17/16th MC/23-11-2018 (2018).

${ }^{25}$ ibid 2-3.

${ }^{26}$ No contracting party met this deadline, although some were more advanced in their work than others. Energy Community, '5th Meeting - Energy and Climate Committee, Vienna, 25 March 2020, Draft Minutes'.

${ }^{27}$ Energy Community Secretariat (n 22) 8.

${ }^{28}$ Energy Community, '53rd Permanent High Level Group, Vienna, 18 September 2019, Conclusions' para 3.

${ }^{29}$ Energy Community, '55th Permanent High Level Group, Chisinau, 12 December 2019, Conclusions' para 16

${ }^{30}$ See further discussion below.

${ }^{31}$ Energy Community, '17th Ministerial Council, Chisinau, 13 December 2019 , Conclusions' para 12
}

works in the Energy Community, which embarks on that adventure from further behind, remains to be seen. ${ }^{32}$

It might indeed be wondered how a 2030 Framework that has only just been introduced in EU Member States can be concurrently implemented in the far more challenging circumstances of the Energy Community. The following section will identify key challenges to implementing the 2030 Framework within the Energy Community.

\section{4 | KEY ISSUES IN ENERGY COMMUNITY 2030 FRAMEWORK IMPLEMENTATION}

To credibly extend the 2030 Framework to the Energy Community, contracting parties and other stakeholders will have to confront a set of interconnected challenges which constrain the Energy Community's ability to transition to more sustainable energy. This article highlights three key challenges, which are interrelated: the hybridity of the Energy Community as a legal space, with the principle of legal homogeneity in tension with a reality of legal pluralism; the ongoing challenge of national implementation; and the lack of adequate dispute settlement procedures. These three challenges have been selected, in addition to their immediate practical salience to 2030 Framework implementation, because of the contrasts they present to the situation prevailing in the EU: a looser and more contested normative framework, more challenging conditions for implementation and weaker dispute resolution mechanisms. The discussion of these challenges will invite consideration of how the extension of EU climate law beyond the EU's own borders is a task of a different nature to internal legal development and implementation, requiring an appropriately modified approach.

\section{1 | A hybrid legal space}

The Energy Community is a treaty framework within which the EU, EnC Secretariat and contracting parties co-create a hybrid legal space. This hybridity consists of the EnC Treaty, EnC procedural law, EU legal acts modified for transposition and the legal systems of the contracting parties themselves. The multiple actors of the Energy Community interact to produce a hybrid legal space, with both substantive and procedural EnC law (defined as 'a Treaty obligation or ... a Decision or Procedural Act addressed to [a party]') ${ }^{33}$ reflecting a mix of (modified) EU law, sui generis EnC structures and the legal orders and cultures of the contracting parties. In this hybrid space, actors such as the European Commission and the Ministerial Council have distinct competences. This hybridity can make implementation of EnC law a complicated undertaking. It also indicates the

\footnotetext{
${ }^{32}$ Energy Community Secretariat, 'Annual Implementation Report' (1 September 2018) 9.

${ }^{33}$ Procedural Act 2008/01/MC-EnC on Rules of Procedure for Dispute Settlement under Treaty as Amended by Procedural Act 2015/04/MC-EnC of 16 October 2015 (Rules of Procedure for Dispute Settlement) art 1.
} 
compromises that may be required to extend climate policy based on EU law beyond the EU's own frontiers.

The diverse actors which together constitute the Energy Community may be considered to amount not to a unified system of normative development and implementation, but rather to a hybrid legal space, which prevails in 'situations in which two or more state and nonstate normative systems occupy the same social field and must negotiate the resulting hybrid legal space'. ${ }^{34}$ The concept of legal pluralism is helpful in drawing out the legal hybridity of the Energy Community and in identifying how this hybridity presents significant challenges for adoption and implementation of the 2030 Framework. Legal pluralism focuses on interactions between different sites of norm production, as captured by Santos' influential formulation of 'interlegality': 'an intersection of different legal orders, ... [resulting] in uneven and unstable mixings of legal codes'. ${ }^{35}$

This study of interactions between 'legal spaces' is particularly salient to transnational legal arrangements such as the Energy Community, which incorporate international, EU, national and non-State (contractual) law. Accounts of legal pluralism include both 'structural' and 'relational' aspects - the former concerning 'institutional, normative, and processual sites' such as States, international organizations and business associations, and the latter concerning the relations between different such 'sites'. ${ }^{36}$ As Snyder and colleagues recently observed, the often-neglected relational aspect of legal pluralism emphasizes 'the potentiality of putting existing but inert institutions, norms and dispute-handling processes into play', as well as 'the relative fluidity and unpredictability of social life rather than assumed order and stability.' ${ }^{37}$

Hybrid legal spaces may have an 'institutional component', such as one focused on an 'inter-governmental model of organization and rule making, ${ }^{38}$ as in the case of the Energy Community. Such regulatory hybridization, exemplified by 'regulatory arrangements which combine elements from several legal orders', has become 'common place.. ${ }^{39}$ While legal pluralists have applied a variety of methodologies to the study of hybrid legal spaces, the approach proposed by Zumbansen of identifying relevant 'actors, norms and processes', and their interactions, has the advantage of structuring the inquiry into key components. ${ }^{40}$

\footnotetext{
${ }^{34}$ PS Berman, Global Legal Pluralism: A Jurisprudence of Law Beyond Borders (Cambridge University Press 2012) 46

${ }^{35}$ B Santos, 'Law: A Map of Misreading. Toward a Postmodern Conception of Law' (1973) 7 Journal of Law and Society 279, 298.

${ }^{36} \mathrm{~F}$ Snyder, 'Governing Economic Globalisation: Global Legal Pluralism and European Law' (1999) 5 European Law Journal 334, 342-343.

${ }^{37}$ F Snyder, Z Hu and L Ni, 'Transnational Law in the Pacific Century: Mapping Pesticide Regulation in China' in P Zumbansen (ed), The Many Lives of Transnational Law: Critical Engagements with Jessup's Bold Proposal (Cambridge University Press 2020) 153.

${ }^{38}$ LC Backer, 'The Emerging Normative Structures of Transnational Law: Non-State Enterprises in Polycentric Asymmetric Global Orders' (2016) 31 Brigham Young University Journal of Public Law 1, 13.

${ }^{39}$ PF Kjaer, 'Introduction' in P Jurcys, PF Kjaer and R Yatsunami (eds), Regulatory Hybridization in the Transnational Sphere (Martinus Nijhoff 2013) 3.

${ }^{40} \mathrm{P}$ Zumbansen, 'Defining the Space of Transnational Law: Legal Theory, Global Governance, and Legal Pluralism' (2012) 21 Transnational Law \& Contemporary Problems 305, 308. See also Bodansky, who is also concerned with the emergence and effect of norms: D Bodansky, The Art and Craft of International Environmental Law (Harvard University Press 2010) 8-9.
}

The Energy Community is a 'quasi supranational legal system modelled on the [European Economic Area] with some elements of legal homogeneity between the contracting parties'. ${ }^{41}$ The Energy Community is not an EU institution, at least in the formal sense. From an international law perspective, the Energy Community is an international institution under a constituting treaty to which the EU is one party. However, as an EU initiative, the Energy Community has been designed so that EU institutions - most directly, the Commission - play decisive roles. The European Commission is tasked to 'act as co-ordinator' of the Energy Community's activities. ${ }^{42}$ The Commission has exclusive power to propose measures for the extension of the EU acquis. ${ }^{43}$ Alongside its monopoly on proposing measures to implement the acquis, the European Commission holds a veto over other developments of EnC substantive and procedural law. ${ }^{44}$

Several institutions established by the EnC Treaty are also charged with governance of the Energy Community. The Ministerial Council is the highest decision-making body and is composed of two representatives of the $\mathrm{EU}$ and one representative of each contracting party. ${ }^{45}$ The Ministerial Council provides general policy guidelines, takes 'Measures' and adopts 'Procedural Acts'. ${ }^{46}$ In practice, the Ministerial Council meets annually. ${ }^{47}$

The EnC Secretariat has responsibility for supporting the work of the EnC decision-making bodies and for reviewing and reporting on implementation of contracting party obligations. ${ }^{48}$ The Secretariat also initiates compliance processes against contracting parties. ${ }^{49}$ In practice, the Secretariat has been a key player, working closely with contracting parties on implementing the growing acquis and developing various elements of EnC governance, such as dispute resolution procedures. ${ }^{50}$

The Secretariat has in recent years taken initiative on climate policy, identifying a strategic direction in various communications and documents. The pithiest expression of this vision is the 'Wachau Manifesto' of 2018, in which the Secretariat asserts that the Energy Community's 'second energy transition' began on the first day of 2018, when the Large Combustion Plants Directive and the Industrial Emissions Directive entered into force. Due to the restrictions that these laws impose on the operation of coal-fired plants, the

\footnotetext{
${ }^{41} \mathrm{R}$ Petrov, 'Energy Community as a Promoter of the European Union's "Energy Acquis" to its Neighbourhood' (2012) 39 Legal Issues of Economic Integration 331, 334

${ }^{42}$ EnC Treaty (n 11) art 4

${ }^{43}$ ibid art 79.

${ }^{44}$ ibid arts $83-87$

${ }^{45}$ ibid art 48.

${ }^{46}$ ibid art 47.

${ }^{47}$ Energy Community, 'Rules of Procedures of Ministerial Council of Energy Community', Procedural Act 2006/01/MC-EnC (17 November 2006), as amended by Procedural Acts 2013/01/MC-EnC (24 October 2013) and 2015/02/MC-EnC (15 October 2015) (Rules of Procedures of Ministerial Council).

48 ibid art 67.

${ }^{49}$ ibid art 90.

${ }^{50} \mathrm{R}$ Karova, 'The Disputes Settlement System of the Energy Community: Testing its Effectiveness' in D Buschle and K Talus (eds), The Energy Community (Cambridge University Press 2015) 25, 54.
} 
Secretariat claims that 2018 was the 'beginning of the end of the coal and lignite era' in the Energy Community. ${ }^{51}$ The manifesto concludes that 'the most important change required is a change in mindset. The Energy Community and its Contracting Parties need to embrace the energy transition, and not fight it. ${ }^{52}$ While reflecting the latest EU thinking on the energy transition, what is most striking about this manifesto is how at odds it is with the practice of most contracting party governments. Far from 'embrac[ing] the energy transition', contracting parties continue to subsidize coal, ${ }^{53}$ attract external financing for fossil fuel expansion and, in many cases, lag behind their 2020 renewable and energy efficiency targets.

The contracting parties are of course central EnC actors themselves. They sit on the Ministerial Council and other EnC bodies alongside the EU, and they are ultimately responsible for implementing EnC law within their own jurisdictions.

The EnC Treaty contains a mechanism for updating the acquis, so that the substance of Energy Community law has not been frozen in 2005. Article 100 provides that the Ministerial Council may, by unanimous decision, amend the EnC Treaty, 'decide to implement other parts of the acquis communautaire related to Network Energy' or 'extend this Treaty to other energy products and carriers or other essential network infrastructures'. ${ }^{54}$ Article 25 provides that ' $[t]$ he Energy Community may take Measures to implement amendments to the acquis communautaire described in this Title, in line with the evolution of European Community law'. ${ }^{55}$ Although it has been noted that this provision does not oblige the Energy Community to adopt changes to the EU acquis, ${ }^{56}$ since the EnC Treaty entered into force, the Ministerial Council has adopted multiple amending Measures. ${ }^{57}$

The interpretation provisions of EnC law aim for a certain conformity with EU case law - albeit in the absence of a competent EnC court to do the interpreting. Article 94 of the EnC Treaty provides that the EnC institutions 'shall interpret any term or other concept used in this Treaty that is derived from European Community law in conformity with the case law of the Court of Justice or the Court of First Instance of the European Communities'. ${ }^{58}$ Where no such interpretation is available, the Ministerial Council 'shall give guidance in interpreting this Treaty'. ${ }^{59}$ However, the Ministerial Council must 'ask the European Commission and the [EnC] Secretariat for a reasoned opinion regarding the interpretative issue specified in the

\footnotetext{
${ }^{51}$ Energy Community Secretariat, 'The Wachau Manifesto' (June 2018) 1-2.

${ }^{52}$ ibid.

${ }^{53}$ D Miljević, M Mumović and J Kopač, 'Rocking the Boat: What is Keeping the Energy Community's Coal Sector Afloat? Analysis of Direct and Selected Hidden Subsidies to Coal Electricity Production in the Energy Community Contracting Parties' (Energy Community Secretariat, June 2019).

${ }^{54} \mathrm{EnC}$ Treaty (n 11) art 100.

${ }^{55}$ ibid art 25

${ }^{56}$ Karova (n 50) 29

${ }^{57}$ See, e.g., Energy Community, 'Decision on the Implementation of Directive 2009/28/ $\mathrm{EC}$ and Amending Article 20 of the Energy Community Treaty', Ministerial Council Decision 2012/04/MC-EnC (18 October 2012).

${ }^{58}$ EnC Treaty (n 11) art 94

${ }^{59}$ ibid.
}

request'. ${ }^{60}$ Similarly, contracting parties must ensure that their national courts, when faced with an issue of EnC law, can notify the EnC Secretariat, ${ }^{61}$ while the public authorities of contracting parties are also to notify the EnC Secretariat when dealing with questions of EnC law. ${ }^{62}$ 'Where the coherent interpretation or application of Energy Community law so requires', the EnC Secretariat submits its opinion, which 'must be in conformity with the case-law of the Court of Justice of the European Union', to the national authority or court. $^{63}$ The 2018 annual report disclosed three instances of national authorities asking for a Secretariat interpretation, with no instances of national courts requesting interpretations recorded. ${ }^{64}$ In the absence of a court, the EnC Secretariat is itself 'de facto working on and developing an interpretation of EnC law'. ${ }^{65}$

This principle of homogeneity of interpretation enshrined in Article 94 of the EnC Treaty is in tension with a reality of plural legal practices. First, the mechanism of national courts and authorities asking for Secretariat interpretations appears little used. Second, the record of inadequate implementation and non-compliant practices discussed below indicates that contracting parties often ignore the homogeneity principle, even where there is no explicit divergence over interpretation. Third, the EU and EnC legal orders concerning energy are in fact so different - due to the limited EnC acquis - as to call into question the salience of the homogeneity principle, other than as a matter of doctrinal formalism. In particular, there is a widening gap concerning climate law which transposition of the 2030 Framework and EnC Treaty reform could address. Two issues illustrate the problem and potential remedies.

First, the EnC acquis is rendered lopsided by the absence of an emissions trading system (ETS) or carbon pricing of any kind. This is absent from both the current and proposed body of EnC law dealing with climate change. The EU ETS sectors (including energy and industry) must reduce their emissions by 43 percent to achieve an overall EU-wide 40 percent emissions reduction. However, achieving corresponding emissions reduction in the $\mathrm{EnC}$ will require other means - a topic of much of the early technical discussion concerning 2030 targets. More fundamentally, the absence of carbon pricing ${ }^{66}$ entrenches a divergence from the EU energy market that is hampering the modernization of EnC power sectors. It has created a perverse incentive to maintain or even expand fossil fuel generation. This is because the recent steep increase in the value of EU emission

\footnotetext{
${ }^{60}$ Rules of Procedures of Ministerial Council (n 47) art VIII(3).

${ }^{61}$ Rules of Procedure for Dispute Settlement (n 33) art 2(2).

${ }^{62}$ ibid art 2(1).

${ }^{63}$ ibid art 2(3). The national authority or court has an obligation to take the Secretariat's opinion into account; ibid art 2(4).

${ }^{64}$ Energy Community Secretariat, 'Report of the Energy Community Secretariat on Enforcement Activities, September 2017-September 2018, Part I: Dispute Settlement Report, Annex 23a/16th MC/13-11-2018' 3

${ }^{65}$ Karova (n 50) 55.

${ }^{66} \mathrm{Alone}$ among the EnC contracting parties, Montenegro has recently introduced legislation for emissions trading. Energy Community Secretariat, 'Montenegro Continues to Take Major Steps to Reduce GHG Emissions as Government Approves Cap and Trade System for Major Emitters' (24 February 2020) <https://energy-community.org/news/ Energy-Community-News/2020/02/24.html>
} 
allowances has made EnC coal undertakings increasingly price competitive vis-à-vis EU-based competitors. ${ }^{67}$ In January 2020, the EnC Secretariat engaged consultants to prepare a study for carbon pricing in the Energy Community. The Secretariat noted that the 'design of any future carbon pricing mechanism should allow for transitional carbon pricing by each Contracting Party (separately or as part of an Energy Community-wide design) and prepare the Contracting Parties for joining the EU ETS in the future. ${ }^{68}$ While extending or replicating the EU ETS may not be feasible or desirable, ${ }^{69}$ some mechanism for pricing carbon is necessary to address the growing divergence between EnC energy undertakings and their EU counterparts.

Second, while the EU's 2030 Framework is designed to be consistent with the EU's Paris Agreement commitment, EnC law has not been updated to respond to the significant changes in international climate law since 2015. In the EnC Treaty, the one reference to international climate law remains Article 13, which provides: 'The Parties recognise the importance of the Kyoto Protocol. Each Contracting Party shall endeavour to accede to it. ${ }^{70}$ This is obsolete, as Kyoto has been superseded by the Paris Agreement, both politically and as the main international legal instrument for coordinating national contributions to climate mitigation. Individually, each contracting party has submitted an NDC with the exception of Kosovo, which is not a party to international climate treaties. ${ }^{71}$ The Ministerial Council has recommended that NECP progress reports 'should [also] facilitate the monitoring and the implementation of commitments taken under the United Nations Framework Convention on Climate Change (UNFCCC) and Paris Agreement'. ${ }^{72}$ To strengthen and facilitate EnC commitment to the Paris Agreement, the Agreement should be included in the text of an amended EnC Treaty.

\section{2 | National implementation}

The substance of Energy Community law comes from the adoption of relevant EU legislation as provided for in the EnC Treaty, typically with modifications to suit the conditions of contracting parties and extended timelines for national transposition and implementation. The EnC Treaty provides that the Energy Community 'shall follow the acquis communautaire described in Title II, adapted to both the institutional framework of this Treaty and the specific situation of

\footnotetext{
${ }^{67}$ Energy Community Secretariat, 'One Year after the Wachau Manifesto - Making the Energy Community Climate and Energy Transition a Success' (20 June 2019) 2.

${ }^{68}$ Energy Community Secretariat, 'Secretariat Launches Study on Carbon Pricing Design in the Energy Community' (3 February 2020) <https://energy-community.org/news/ Energy-Community-News/2020/02/03.html>.

${ }^{69}$ S Bogojević, Emissions Trading Schemes: Markets, States and Law (Hart 2013) 68; A Boute, 'The Impossible Transplant of the EU Emissions Trading Scheme: The Challenge of Energy Market Regulation' (2017) 6 Transnational Environmental Law 59, 83.

${ }^{70}$ EnC Treaty (n 11) art 13

${ }^{71}$ For a summary of NDCs, see Energy Community Secretariat (n 32).

${ }^{72}$ Energy Community, 'Preparing for the Development of Integrated National Energy and Climate Plans by the Contracting Parties of the Energy Community', Recommendation of the Ministerial Council of the Energy Community 2018/1/MC-EnG (2018) art 4(1).
}

each of the Contracting Parties, with a view to ensuring high levels of investment security and optimal investments'. ${ }^{73}$ Parties must 'take all appropriate measures, whether general or particular, to ensure fulfilment of the obligations arising out of this Treaty', and must 'abstain from any measure which could jeopardise the attainment of the objectives of this Treaty'. ${ }^{74}$

The mechanism for implementing the substantive law contained in Title II is the adoption of Measures, typically by the Ministerial Council, 'adapting' the acquis, 'taking into account both the institutional framework of this Treaty and the specific situation of each of the Contracting Parties.' ${ }^{75}$ Contracting parties must 'implement Decisions addressed to them in their domestic legal system within the period specified in the Decision.' ${ }^{76}$

The circumstances of EnC contracting parties make national implementation of the acquis more challenging than in the EU. Unlike the non-EU members of the European Economic Area, most EnC contracting parties lag far behind the EU average on economic development and rule of law indicators, resulting in integration challenges of a different order. Many contracting parties have endured political instability in their recent past (or present), while Ukraine is mired in ongoing violent conflict within its borders. Moreover, the functioning of the Energy Community is impeded by fundamental political disagreements between contracting parties, which have no parallel within the EU. For example, the 2019 Ministerial Council was hosted by Moldova, which refused to accept the 'travel documents issued by the authorities of Kosovo'. As a result, not only was Kosovo unrepresented, but Albania and North Macedonia boycotted the meeting in solidarity with Kosovo. ${ }^{77}$

The energy mix of contracting parties is a further point of differentiation. More than 46 percent of the contracting parties' total installed electricity generation capacity is from coal. ${ }^{78}$ This situation is entrenched by the most coal-dependent contracting parties continuing to allocate greater subsidies to coal than to renewables. ${ }^{79}$

In this context, implementing EnC law has proved a significant burden for contracting parties. In its 2018 annual report, the EnC Secretariat rated the average for contracting party implementation of EnC commitments at 43 percent. ${ }^{80}$ To progress from this inadequate implementation of its current acquis to robust implementation of the 2030 Framework, the Energy Community will require a step change. A review of the EnC Secretariat's 2018 reporting in the area of renewable energy illustrates both the scale of the implementation challenge and the diversity of problems faced in contracting parties, from the absence of needed secondary legislation, ${ }^{81}$ to 'lengthy and

\footnotetext{
${ }^{73}$ EnC Treaty (n 11) art 5.

${ }^{74}$ ibid art 6.

${ }^{75}$ ibid art 24.

${ }^{76}$ ibid art 89.

${ }^{77}$ Energy Community (n 31) para 5.

${ }^{78}$ Miljević et al (n 53) 5

${ }^{79}$ ibid.

${ }^{80}$ Energy Community Secretariat (n 32) 7.

${ }^{81}$ ibid 31 (concerning Albania).
} 
burdensome' permitting procedures for renewable projects, ${ }^{82}$ to the inadequate staffing of key agencies. ${ }^{83}$ Implementation of EnC obligations has challenged the judiciaries of contracting parties as well as their executives. ${ }^{84}$ Moreover, political instability has impeded implementation in several contracting parties. ${ }^{85}$

A recent study of the Europeanization of energy law in Georgia is illustrative. As the Energy Community prepares to incorporate the 2030 Framework, Georgia remains non-compliant with a litany of Third Energy Package obligations (not including obligations for which it has an exemption). Enforcement is a major issue, as the Energy Community sets deadlines but does not operate a 'supranational surveillance authority should Georgia not deliver on promises'. ${ }^{86}$ Samkharadze concludes that a 'simple "copy-paste" approach of harmonising national laws does not suffice for a successful legal harmonisation. EU energy law must be exported creatively to enhance the capacity of an energy market reform. ${ }^{, 87}$

The case of Georgia underlines the significance of the (as yet undetermined) extent to which EnC processes for the 2030 Framework match the 'significantly strengthened' supervisory role of the European Commission for 2030 implementation within the EU (as compared to the 2020 Framework). ${ }^{88}$ More broadly, it indicates that the reception and implementation of the acquis by EnC contracting parties should not be reduced to the 'simplistic "transplant" model' of '"cut and paste" lawmaking' that has sometimes been observed in the climate field, ${ }^{89}$ and more generally in the adoption of substantive law in post-Socialist countries. ${ }^{90}$ The 'powerful metaphor of the "legal transplant"' mischaracterizes

\footnotetext{
${ }^{82}$ ibid 155 (Serbia).

${ }^{83}$ For example, there was 'not a single energy efficiency expert' in North Macedonia's Department for Energy; ibid 110

${ }^{84}$ Petrov (n 41) 331, 343ff

${ }^{85}$ For instance, Ukraine under former President Yanukovich repeatedly announced an intention to withdraw from the Energy Community. D Buschle, 'Exporting the Internal Market - Panacea or Nemesis for the European Neighbourhood Policy? Lessons from the Energy Community' (College of Europe 2014) 6 .

${ }^{86}$ ibid.

${ }^{87}$ I Samkharadze, 'Europeanization of Energy Law and Policy beyond the Member States: The Case of Georgia' (2019) 130 Energy Policy 1, 6.

${ }^{88} \mathrm{~S}$ Oberthür, 'Hard or Soft Governance? The EU's Climate and Energy Policy Framework for 2030' (2019) 7 Politics and Governance 17, 18

${ }^{89} \mathrm{~N}$ Affolder, 'Melting the Boundaries of Law: Transnational Climate Law and Practice' in P Zumbansen (ed), The Oxford Handbook of Transnational Law (Oxford University Press $2020 \mathrm{fc})$.

${ }^{90} \mathrm{D}$ Berkowitz, K Pistor and JF Richard, 'The Transplant Effect' (2003) 51 American Journal of Comparative Law 163, 164-165. The 'legal transplant' concept has been much discussed in the energy and climate change law literature. In addition to the references otherwise cited, see, e.g., G Bellantuono, 'Comparative Energy Law: Some Methodological Issues' (2011) 9 Oil, Gas \& Energy Law Intelligence; DV Popović, 'Institutional Design of State Aid Authorities in South East Europe: The Unfit Legal Transplant and its Ramifications' in B Begović and DV Popović (eds), Competition Authorities in South Eastern Europe: Building Institutions in Emerging Markets (Springer 2018) 63 (concerning State aid in the EnC context); A Boute, 'Improving the Climate for European Investments in the Russian Electricity Production Sector: (II) The Role of Regulatory Convergence' (2008) 26 Journal of Energy and Natural Resources Law 327; D Azaria, 'Energy Transit under the Energy Charter Treaty and the General Agreement on Tariffs and Trade' (2009) 27 Journal of Energy and Natural Resources Law 559; H Prange-Gstohl, 'Enlarging the EU's Internal Energy Market: Why Would Third Countries Accept EU Rule Export?' (2009) 37 Energy Policy 5296; and N Affolder, 'Looking for Law in Unusual Places: Cross-Border Diffusion of Environmental Norms' (2018) 7 Transnational Environmental Law 425.
}

the interaction between the transposed norm and the receiving jurisdiction by assuming a surgical dichotomy of 'integration' or 'repulsion'. ${ }^{91}$ Teubner proposes instead the notion of 'legal irritant', which 'triggers a whole series of new and unexpected events' in the receiving legal arrangements, 'forc[ing] them to reconstruct internally not only their own rules but to reconstruct from scratch the alien element itself'. ${ }^{92}$ This allowance for complex interactions better captures the realities of a hybrid legal space such as the Energy Community, in which transposed laws and legal procedures must indeed be reconstructed rather than transplanted.

\section{3 | Dispute resolution}

The enforcement of contracting party obligations is hampered by a political compliance procedure that in practice rarely punishes non-compliance. This is likely to hinder 2030 Framework implementation, although the recent establishment of an EnC mediation centre could ameliorate the situation. The EnC Treaty provides that if a party is breaching a Treaty obligation or failing to implement a Decision, the matter can be referred to the Ministerial Council by 'reasoned request' of another party, the Secretariat or the Regulatory Board. ${ }^{93}$ However, the process for resolving such disputes is ultimately political and not judicial. The Ministerial Council may determine by vote that a party has breached EnC obligations. In each case, the vote of the accused party is not taken into account. ${ }^{94}$ But, also in each case, the decision is purely declaratory, and any decision finding a party in breach may be overturned by simple majority. ${ }^{95}$ While a party determined by a unanimous vote of the Ministerial Council under Article 92 to be in 'serious and persistent breach' of its obligations may have its voting and participation rights suspended, ${ }^{96}$ this procedure has proven inapt for resolving routine non-compliance matters. The absence of a court empowered to issue binding rulings on non-compliance was a conscious choice of the parties which negotiated the EnC Treaty. ${ }^{97}$

The EnC Treaty provisions on dispute settlement were supplemented by Dispute Settlement Procedures, adopted in 2008 and updated in 2015 in response to EU dissatisfaction with the status quo. ${ }^{98}$ The Procedures provide for an Advisory Committee of five

${ }^{91} \mathrm{G}$ Teubner, 'Legal Irritants: Good Faith in British Law or How Unifying Law Ends Up in New Divergences' (1998) 61 Modern Law Review 11, 12.

${ }^{92}$ ibid.

${ }^{93}$ EnC Treaty (n 11) art 90(1)

${ }^{94}$ ibid art 93.

${ }^{95}$ ibid arts 91(2) and 92(2)

${ }^{96}$ ibid art 92(1).

${ }^{97} \mathrm{H}$ Schmitt von Sydow, 'Die paneuropäische Energiegemeinschaft mit Südosteuropa' in A Epiney et al (eds), Die Herausforderung von Grenzen - Le défi des frontières - Challenging Boundaries: Festschrift/Mélanges en l'honeur de/Essays in honor of Roland Bieber (Nomos 2007) 13, cited in D Buschle, 'The Enforcement of European Energy Law Outside the European Union: Does the Energy Community Live Up to the Expectations?' (2016) 6 European Energy Journal 26, 28.

${ }^{98}$ European Parliament, 'Resolution of 23 October 2013 on the European Neighborhood Policy: Towards a Strengthening of the Partnership, 2013/2621(RSP)', cited in Rules of Procedure for Dispute Settlement (n 33) preamble. 
independent legal experts, 'who possess the qualifications required for appointment to the highest judicial offices in the respective Party' to provide its opinion on the reasoned request prior to Ministerial Council consideration of the dispute. ${ }^{99}$ While the Advisory Committee's opinion does not bind the Ministerial Council, ${ }^{100}$ the opinion is appended to the Ministerial Council's decision and is publicly available. ${ }^{101}$ As Buschle has observed, '[b]y proposing to ministers the legally "correct" decision - a proposal which is made public - it becomes practically very difficult for the decision-makers to deviate'. ${ }^{102}$ Nevertheless, the procedure remains diplomatic rather than judicial. Moreover, as the Ministerial Council meets only once a year, it 'resembles a feudal jurisdiction in medieval times rather than a modern-day dispute resolution body'. ${ }^{103}$

The EnC Secretariat also lacks enforcement powers that the European Commission may employ regarding many energy matters in the EU. The Secretariat has no power to bring court action against a party for non-compliance, ${ }^{104}$ being restricted instead to the process discussed above. Nor can the Secretariat issue fines, secure binding commitments or make orders regarding incompatible State aid. ${ }^{105}$ Overall, the effect of the formally compulsory and binding dispute resolution procedure was summarized by the European Commission, with perhaps unintended irony: 'The dispute settlement mechanism provided for in the Treaty has proved efficient in cases where parties were open to negotiating an amicable solution.' $^{106}$

Recent Secretariat reporting indicates the practical limitations of the current framework. As of September 2018, 62 cases had been closed under Article 91 (determination of breach at first instance) and two cases had been closed under Article 92 ('serious and persistent breach'). However, the Ministerial Council had adopted a decision in only 16 of the Article 91 cases, while both Article 92 cases had resulted in Ministerial Council decisions. A further 26 cases remained open. ${ }^{107}$ Some cases have remained open for years. ${ }^{108}$ In many of the closed cases, the Secretariat has withdrawn its request for Ministerial Council decision after a contracting party has agreed steps to bring itself into compliance. ${ }^{109}$ However, there are also cases in which contracting parties have essentially ignored unfavourable (and sometimes multiple)

\footnotetext{
${ }^{99}$ ibid art 32.

${ }^{100}$ ibid.

${ }^{101}$ ibid art 34(3).

${ }^{102}$ Buschle (n 97) 30.

${ }^{103}$ ibid 32.

${ }^{104}$ As can the European Commission under Consolidated Version of the Treaty on the Functioning of the European Union [2008] OJ C115/49 art 258.

${ }^{105}$ State aid accounts for a large proportion of the EnC disputes case load.

${ }^{106}$ Commission (EU), 'Report from the Commission to the European Parliament and the Council under Article 7 of Decision 2006/500/EC' COM(2011) 105 final, 10 March 2011, 6

${ }^{107}$ Energy Community Secretariat (n 64)

${ }^{108}<$ https://energy-community.org/legal/cases.html>

${ }^{109}$ Rules of Procedure for Dispute Settlement (n 33) art 19(1).
}

Ministerial Council decisions. In 2018, the Secretariat listed five such cases.

In one of these cases, the EnC Secretariat issued a first reasoned request in 2013, alleging Bosnia and Herzegovina to be in breach of multiple elements of the energy acquis concerning gas. ${ }^{110}$ The Advisory Committee concluded that $\mathrm{BiH}$ was in breach of 12 distinct points of EnC law. ${ }^{111}$ However, despite a Ministerial Council decision under Article 91 determining a breach and three subsequent Article 92 decisions finding 'serious and persistent breach', $\mathrm{BiH}$ continues to flout its obligations. The Secretariat concluded in 2018 that $\mathrm{BiH}$ 'continues to seriously infringe Energy Community law despite the Ministerial Council having already adopted four Decisions' between 2013 and $2016 .{ }^{112}$ The delays in implementation of the acquis by $\mathrm{BiH}$ go as far back as $2007,{ }^{113}$ and the law at the heart of the dispute Directive 2003/55 - has meanwhile been superseded by the Third Energy Package.

Notwithstanding the limitations of this Treaty-based dispute settlement process, there has been some successful introduction of alternative dispute resolution. In 2016, the EnC Secretariat established a Dispute Resolution and Negotiation Centre, which is attached to the Legal Unit of the Secretariat. The Centre offers mediation of compliance disputes between the Secretariat and contracting parties, in order to reach a mutually acceptable resolution prior to submission of the matter to the Ministerial Council. ${ }^{114}$ It also offers to mediate disputes between States, public authorities and businesses, and to facilitate energy negotiations involving parties. The Centre aims to expedite procedures, with a default maximum period of three months for third-party disputes. ${ }^{115}$ In the case of compliance disputes, it also invites any complainant (e.g. a business or nongovernmental organization) to be present, 'unless the Party concerned objects based on legitimate reasons of overriding interest'. ${ }^{116}$ The Centre has built an impressive roster of independent mediators ${ }^{117}$ and there has been demand for its services mediating third-party disputes and facilitating negotiations. ${ }^{118}$ It is unclear whether mediation of compliance disputes will become a significant adjunct to the Treaty-based dispute settlement procedure, and it should be recalled that participation in the Centre's processes is entirely voluntary. Nevertheless, as mediation assumes a new prominence internationally with the adoption of the Singapore Convention on Mediation, the role of the Centre will require further study.

\footnotetext{
${ }^{110}$ Energy Community Secretariat, 'Reasoned Request in Case ECS-8/11' (21 May 2013).

${ }^{111}$ Advisory Committee, 'Opinion', Case ECS-8/11 (11 September 2013).

${ }^{112}$ Energy Community Secretariat (n 64) 2.

${ }^{113}$ Energy Community Secretariat (n 110) para 40

${ }^{114}$ Energy Community Secretariat, 'Procedural Act of the Energy Community Secretariat 2018/5/ECS on the Establishment of a Dispute Resolution and Negotiation Centre' (25 October 2016) Title III.

${ }^{115}$ ibid art 8(3).

${ }^{116}$ ibid art 18

${ }^{117}<$ https://author.energy-community.org/enc-author-prd/enc/aboutus/disputeresoluti on/mediators.html>.

${ }^{118}$ Energy Community Secretariat (n 64) 4.
} 
Even before the Energy Community adopts legislation for the 2030 Framework, its present dispute settlement system is grappling with issues of great significance for the carbon footprint of contracting parties. The issue of State aid for new coal projects is an example which illustrates, consistent with broader developments in climate adjudication, ${ }^{119}$ that 'climate cases' are a far broader category than matters concerning dedicated climate legislation. In 2017, the Export Import Bank of China (China Exim) agreed to provide a loan of €613.9 million to Elektroprivreda $\mathrm{BiH}$ d.d. Sarajevo, a public utility in $\mathrm{BiH}$, for the development of the 450-megawatt Tuzla 7 thermal power plant unit. The $\mathrm{BiH}$ government agreed to provide China Exim with a 100 percent guarantee of the loan, exercisable should Elektroprivreda default. The EnC Secretariat alleges that the guarantee constitutes State aid and began dispute resolution proceedings against $\mathrm{BiH}$ in March 2019. An advice commissioned by the EnC Secretariat from external counsel concluded that the guarantee constitutes State aid, such that the $\mathrm{BiH}$ Parliament could not lawfully have approved it. ${ }^{120}$ Following the commencement of proceedings, the $\mathrm{BiH}$ State Aid Council requested an 'interpretation of the criteria excluding State aid contained in the European Commission's Notice on guarantees' from the Secretariat. ${ }^{121}$ Also at BiH's request, the dispute was submitted to mediation within the EnC Dispute Resolution and Negotiation Centre. ${ }^{122}$

While the Tuzla case turns on the competition acquis, the project's inconsistency with EU climate law and policy is central to the Tuzla fact pattern. ${ }^{123}$ As the advice from SheppardMullin notes, 'it is not disputed that a number of large international and EU-based financial institutions would not have financed the Tuzla 7 project .. since they no longer finance coal power plants'. ${ }^{124}$ This exit from coal financing by banks such as the European Bank for Reconstruction and Development ${ }^{125}$ and the European Investment Bank ${ }^{126}$ has not only resulted in the absence of a market benchmark price for the guarantee, consistency with which could rule out State aid. ${ }^{127}$ It also indicates that massive State aid may be required to lure 'lenders of last resort' such as China Exim in an energy financing market turning

\footnotetext{
${ }^{119}$ See, e.g., Columbia Law School and Arnold \& Porter, 'Climate Change Litigation Databases' <http://climatecasechart.com/>.

${ }^{120}$ SheppardMullin, 'Memorandum, Tuzla 7 Project: Review under EU State Aid Rules of the Guarantee Granted by Bosnia Herzegovina' (4 March 2019).

${ }^{121}$ Energy Community Secretariat (n 32) 202.

${ }^{122}$ ibid.

${ }^{123}$ In 2018, directives regulating the emissions of existing and new large combustion plants entered into force in the Energy Community, prompting the Secretariat to warn that compliance 'will require financial resources on an unprecedented scale'. Miljević et al (n 53) 7. Moreover, the nongovernmental organization CEE Bankwatch Network has argued that Tuzla 7 risks becoming a 'stranded asset' if a carbon price is imposed. CEE Bankwatch Network, 'Chinese-Financed Coal Projects in Southeast Europe: A Real and Immediate Threat to the EU's Decarbonisation Efforts' (April 2019) 9.

${ }^{124}$ SheppardMullin (n 120) para 62

${ }^{125}$ European Bank for Reconstruction and Development, 'Energy Sector Strategy 2019-2023' (as approved by the Board of Directors at their meeting of 12 December 2018) <https://www.ebrd.com/cs/Satellite?c=Content\&cid=1395236704077\&pagen ame=EBRD\%2FContent\%2FHublet $>$

${ }^{126}$ European Investment Bank, 'EIB Energy Lending Policy: Supporting the Energy Transformation' (adopted by the EIB's Board of Directors on 14 November 2019) <https://www.eib.org/attachments/strategies/eib_energy_lending_policy_en.pdf>. ${ }^{127}$ Commission (EU), 'Commission Notice on the application of Articles 87 and 88 of the
} EC Treaty to State aid in the form of guarantees' [2008] C155/2 para 3.2. against new coal infrastructure. ${ }^{128}$ In the context of the present dispute resolution system's shortcomings, it is noteworthy that the $\mathrm{BiH}$ government responded to the Secretariat's opening letter by declaring that the project 'will be built regardless of the procedures conducted by the EnC Secretariat'. ${ }^{129}$ Such cases bode poorly for the enforcement of whatever 2030 targets may be adopted in the Energy Community. However, while the hybrid legal space of the Energy Community is currently characterized by weak dispute resolution capacity, this need not remain so.

\section{5 | DISCUSSION: NAVIGATING PLURALISM, TOWARDS TRANSITION}

The unfinished process of extending the 2030 Framework to the Energy Community has spotlighted the possibilities and challenges of implementing climate policy in a hybrid legal space. It has also suggested some conclusions about the role of EU law in such a space, as part of the EU's external action repertoire for promoting its climate policies and objectives. The Energy Community has been a hybrid legal space from the beginning. The EnC legal order is not static but has seen significant alteration and development since the EnC Treaty entered into force. This hybridity, marked by a plurality of actors, norms and processes quite different to their counterparts in the $\mathrm{EU}$, is a feature of the Energy Community. The EnC Treaty established a structured and iterative interaction between the EU, contracting parties and EnC bodies for the development and implementation of EnC law. Within this structure, multiple normative systems (of the EU, the Energy Community and the contracting parties) have negotiated the governance of a particular social field (the energy sector in contracting parties). To this normative diversity, the Treaty applies a logic of convergence, through the mechanism of acquis transposition and the principle of homogeneity. However, there is an evident risk that climate policy in general and the 2030 Framework in particular may exacerbate the countervailing trend toward divergence between the EU and the EnC contracting parties. The risk is that the normative 'irritant' of urgent climate action, introduced from outside the contracting parties by the EU, will not be sufficiently internalized by contracting parties which have other priorities (as the ongoing fossil fuel subsidies and transactions such as Tuzla 7 demonstrate).

Avoiding this risk, and implementing the 2030 Framework in the Energy Community alongside the EU, appears to be a matter of successfully managing legal pluralism. The starting point is acceptance that total convergence by the Energy Community on EU standards is not possible, or in any case will not be brought about by 'legal transplants'. Rather, attention should be focused, first, on reducing the

\footnotetext{
${ }^{128}$ Institute for Energy Economics and Financial Analysis, 'IEEFA Report: Every Two Weeks a Bank, Insurer or Lender Announces New Coal Restrictions' (26 February 2019) <http://ieefa.org/ieefa-report-every-two-weeks-a-bank-insurer-or-lender-annou nces-new-coal-restrictions/>

${ }^{129}$ V Spasić, 'Government Defiant on Tuzla 7 Coal Project, as Energy Community Launches Dispute Settlement Procedure' (Balkan Green Energy News, 29 March 2019).
} 
key mismatches that impede the extension of even a modified 2030 Framework to the Energy Community, and, second, on targeted, in-country implementation that is appropriate to national circumstances and legal systems and cultures.

This article has identified major substantive, institutional and normative mismatches between the EU and the Energy Community that hamper the extension of the 2030 Framework to the latter. While a certain tension between the homogeneity principle and pluralist practice seems structurally embedded in the Energy Community, the most glaring disparities with EU law can be addressed through transposition, Treaty reform and other interventions. These mismatches include the limitations to EnC enforcement and dispute settlement, the lack of carbon pricing in most contracting parties and - more broadly but no less significantly - the comparative dearth of normative commitment to climate action in contracting party governments. The EU, as the party that can propose changes to the EnC acquis and as the party with the greatest political interest in extending the 2030 Framework to the Energy Community, is the party that can take the initiative to address these mismatches with the provision of appropriate legal and financial tools and enhanced political commitment.

The Energy Community's enforcement deficit looms as a major mismatch with the EU regarding the 2030 Framework. Within the EU, the 2030 Framework and especially the Governance Regulation 'provide significant means supporting accountability and effective implementation', including infringement proceedings involving the European Commission and Court of Justice of the European Union, enforcement of direct effect norms through national courts and the Commission's enhanced monitoring role. ${ }^{130}$ Under the EnC dispute settlement system, there is a risk that contracting parties will accept a 2030 Framework on the basis of international legal commitments, but without effective international legal mechanisms to enforce compliance. The EnC Secretariat has argued that closing the 'enforcement gap' with the EU may 'require access to the European courts', while warning that 'current discussions on Treaty amendments risk to fall short in ambition in this respect'. ${ }^{131}$ An alternative approach would be the adoption of a Kyoto Protocol-style compliance mechanism with the power to suspend participation from relevant markets or financial mechanisms. ${ }^{132}$

The still-developing Tuzla case illustrates the practical significance to climate mitigation of a well-functioning EnC dispute settlement system. It also points to an urgent need to embed the 'telos of combating climate change ${ }^{133}$ in EnC dispute resolution. Both of these purposes could be served by the introduction, via EnC Treaty reform, of a compulsory judicial or arbitral process. Moreover,

\footnotetext{
${ }^{130}$ Oberthür (n 88) 23-24.

${ }^{131}$ Energy Community Secretariat (n 67) 2.

${ }^{132}$ UNFCCC 'Decision 27/CMP.1, Procedures and Mechanisms Relating to Compliance under the Kyoto Protocol' UN Doc FCCC/KP/CMP/2005/8/Add.3 (30 March 2006) Annex, Part XV, 4-5. For example, such a compliance committee could suspend contracting parties from participating in the renewable development platform (Parliament and Council Directive (EU) 2018/2001 on the promotion of the use of energy from renewable sources (recast) [2018] OJ L328/82 art 8), in the event that this is incorporated into EnC law.

${ }^{133}$ Buschle (n 97) 241.
}

existing efforts to inculcate a normative commitment to climate action in contracting party governments, including through the engagement of civil society, should be intensified.

The absence of carbon pricing in the Energy Community is a structural mismatch that undercuts the EnC clean energy transition and entrenches divergence from the EU energy market (a problem exacerbated by the persistence of fossil fuel subsidies). The EnC Secretariat's commissioning of research on EnC carbon pricing models is a promising step in this regard, but clearly the situation will not move without significant commitment from the European Commission. At a time when carbon border adjustment mechanisms are on the EU agenda in the context of the European Green Deal, ${ }^{134}$ it would make limited sense to leave this mismatch to fester.

The mismatches identified above partly result from the Energy Community's origin as an organization focused on the liberalization and regional integration of post-Socialist energy sectors, with scant attention paid to climate change (although, as has been seen, the EnC Treaty makes reference to the Kyoto Protocol). This 'first energy transition' has been difficult enough, and remains incomplete, ${ }^{135}$ but at least it is the agenda that contracting parties signed up for. In contrast, decarbonization has become a prominent part of the EnC agenda only in recent years, championed by the European Commission and EnC Secretariat. This 'second energy transition' is arguably more difficult for the Energy Community, because of the need to implement legislation concurrently with the EU rather than following the EU, and because of the absence of political will and technical capacity in many contracting parties.

Given these factors, it might be questioned whether the Energy Community is an apt mechanism for strengthening climate mitigation in the contracting parties. However, due to the central importance of decarbonization in EU energy law (especially since the Clean Energy Package), it is clear that the EnC goal of 'a single regulatory space for trade in Network Energy ${ }^{\prime 136}$ encompassing both the EU and contracting parties cannot be achieved unless energy decarbonization is also addressed in the Energy Community. The Energy Community cannot achieve its stated purposes without incorporating and implementing the EU climate acquis as far as it is relevant to the energy sector. To build capacity in contracting parties to achieve this, the EnC Secretariat should continue to expand collaboration with relevant multilateral climate bodies, in addition to its existing EU and development institution partners. Through the UNFCCC Technology Mechanism, Georgia has recently received technical assistance ${ }^{137}$ and Ukraine has conducted a technology needs assessment. ${ }^{138}$ While not

${ }^{134}$ Commission (EU), 'The European Green Deal' (Communication) COM(2019) 640 final, 11 December 2019, 5; see also MA Mehling et al, 'Designing Border Carbon Adjustments for Enhanced Climate Action' (2019) 113 American Journal of International Law 433.

${ }^{135}$ Energy Community Secretariat (n 51) 1.

${ }^{136} \mathrm{EnC}$ Treaty (n 11) art 2(1)(b).

${ }^{137}$ Climate Technology Centre and Network, 'Georgian Coal Mine Methane Development Project' <https://www.ctc-n.org/technical-assistance/projects/georgian-coal-minemethane-development-project>.

${ }^{138}$ UNEP DTU Partnership, 'Ukraine's First TNA Report Sets Course for Mitigation Action' (7 August 2019) <https://unepdtu.org/ukraines-first-tna-report-sets-cours e-for-mitigation-action/> 
all contracting parties will be eligible for these particular forms of assistance, they are examples of the significant multilateral support currently available.

More successful national implementation may also require better accounting for the complex relationship between the transposed norm and the receiving legal system. The challenge 'calls neither for less nor for different rules as the EU's rules, but for rules adapted to the specific needs of the law-importing countries in a smarter way.' ${ }^{139}$ The question is how to so target the adaptation of rules. Flexibility in transposition and implementation does not mean flexibility in legal commitments. Regarding the latter, in 2014 the High Level Reflection Group mandated by the EnC Ministerial Council to recommend reforms recommended the introduction of 'variable geometry', allowing contracting parties to choose whether to 'opt in' to different laws. ${ }^{140}$ Such an approach would create an Energy Community à la carte, regularizing the current patchwork of implementation, and would undermine the objective of a single energy market.

Instead, the Energy Community could further build its capacity to evaluate the particular circumstances of contracting parties, in preparation for legal transposition. These circumstances include post-Socialist legal and administrative systems and cultures, resource limitations and challenging energy sector profiles. This focus is necessary because, despite the popularity of the 'legal transplant' model in climate policy as discussed above, study of the 'hidden depths of climate law' reveals national contextual factors to be salient to the outcomes of climate-relevant legislation in different jurisdictions. ${ }^{141}$ Such national 'contextual factors' include national climate circumstances, governance frameworks and legal culture. As Scotford and Minas conclude, 'explicit identification of legal contextual factors may prevent erroneous assumptions about the development and implementation of superficially similar climate-relevant legislation across different jurisdictions, whilst opening up relevant lines of inquiry in investigating how legal systems intersect with climate policy initiatives'. ${ }^{142}$

Finally, the situation of the Energy Community indicates that law has an important role to play in aligning third countries with the goals and structures of the 2030 Framework. It should be acknowledged that the Energy Community occupies an unusual position, as most of its contracting parties are near neighbours of the EU and aspire to EU membership. In such circumstances, the logic of extending the EU acquis is clear. Nevertheless, the appeal of access to the EU market and consistency with EU standards is by no means limited to the EU's immediate neighbourhood. Rather, the EU's position as a 'regulatory superpower' enables, in certain sectors, the 'global reach of EU law'. ${ }^{143}$ The mobilization of law in

\footnotetext{
${ }^{139}$ Buschle (n 85) 18.

${ }^{140}$ Energy Community, 'An Energy Community for the Future, Report by the High Level Reflection Group of the Energy Community' (May 2014) 17-18.

${ }^{141}$ E Scotford and S Minas, 'Probing the Hidden Depths of Climate Law: Analysing National Climate Change Legislation' (2019) 28 Review of European, Comparative and International Environmental Law 67.

${ }^{142}$ ibid 80

${ }^{143}$ E Fahey, The Global Reach of EU Law (Routledge 2017).
}

the EU's external climate action can therefore build on both the EU's 'structural leadership', including its economic power, and its 'exemplary leadership' in developing effective climate legislation. ${ }^{144}$

In this context, the Energy Community is a still-developing case study of the extension of the 2030 Framework to countries with significantly different circumstances to the EU. It suggests that the transposition of legislation to third countries can assist in improving alignment with the 2030 Framework and EU climate policy generally. However, this is possible only if the challenges discussed above are addressed. In particular, convergence should be sought in key areas such as carbon pricing and dispute resolution, and there should be appropriate focus on context-appropriate implementation.

Moreover, to the extent that other third countries which choose to cooperate with the EU on climate law are more distant than the Energy Community regarding national circumstances and legal systems, it is likely that a lower level of legal alignment would be possible. Such circumstances will call for the co-creation of hybridized laws and not for 'legal transplants'. In January 2020, the Council of the EU noted the 'importance of pursuing tailor-made approaches for cooperation with third countries ... This means advocating for specific actions from others, based on robust analysis of where results can be achieved. ${ }^{145}$ These conclusions, regarding climate diplomacy, can also be readily applied to cooperation on climate law.

\section{6 | CONCLUSION}

By the summer of 2019, the Clean Energy Package had been fully legislated at the EU level. ${ }^{146}$ Planning for 2030 targets and NECPs was well underway within the Energy Community. However, one year after the release of EnC Secretariat's 'Wachau Manifesto', a stocktaking paper made for grimmer reading. The Secretariat warned that 'the gap between the increasingly ambitious decarbonisation policy in the EU and the lack of ambition in most Contracting Parties became even wider. What is more, it threatens to undermine the future of the Energy Community as an energy and climate integration tool', ${ }^{147}$ a perspective that is echoed by independent experts. ${ }^{148}$ Regrettably, the COVID-19 pandemic is further hindering the energy transition in the Energy Community although, as in the EU, thinking has turned to '[t]urning a disaster into an opportunity'. ${ }^{149}$

\footnotetext{
${ }^{144} \mathrm{H}$ Walker and $\mathrm{K}$ Biedenkopf, 'The Historical Evolution of EU Climate Leadership and Four Scenarios for its Future' in Minas and Ntousas (n 17) 34.

${ }^{145}$ European Council (n 2) para 8.

${ }^{146}$ Commission (EU), 'Clean Energy for All Europeans Package Completed: Good for Consumers, Good for Growth and Jobs, and Good for the Planet' (22 May 2019) <https:// ec.europa.eu/info/news/clean-energy-all-europeans-package-completed-good-consu mers-good-growth-and-jobs-and-good-planet-2019-may-22_en>.

${ }^{147}$ Energy Community Secretariat ( $\mathrm{n} 67$ ) 1.

${ }^{148}$ M Kušljugić, 'Political Economy of Energy Transition in Energy Community' (Balkan Green Energy News, 8 February 2019) <https://balkangreenenergynews.com/polit ical-economy-of-energy-transition-in-energy-community/>.

${ }^{149}$ Energy Community Secretariat, 'Energy Investments and Financing during and Post COVID-19 Crisis' (28 April 2020).
} 
The 2030 Framework is a new test for this hybrid legal space, in that the Energy Community will be implementing the framework in parallel with the EU, rather than learning from and adapting prior EU experiences. The success or failure of the 2030 Framework in the Energy Community will also be an important indicator of the applicability of the EU's policy framework to third countries. The EU's role as a climate policy leader can 'be partially traced to its creation of models capable of transplantation elsewhere.' ${ }^{150}$ This external dimension increases in importance as the EU share of global emissions declines. The objective is not sustainability in one continent, but rather leadership of a global movement towards climate neutrality. In this context, the Energy Community is a reminder that the effect of EU law need not stop at the Union's frontiers. However, the EnC experience is also a warning that the challenge is not just to transpose pieces of legislation, but to ground other countries and regions in the EU's normative approach to climate change.

Doing so may require both a more holistic and more contextual approach to functional integration than was necessarily appreciated in the past. The Energy Community has been described as a 'less idealistic way of integrating neighbouring states into the EU's sphere of economic influence', with EU standards regarding civil, political and social rights 'generally bypassed'. ${ }^{151}$ However, the experience of the Energy Community as a hybrid legal space with inadequate national implementation and limited dispute resolution suggests that contracting parties cannot be effectively integrated into the energy acquis, in isolation from broader legal and normative standards. Rather, effective implementation now appears inseparable from the broader imperatives of developing a 'culture of legality ${ }^{\prime 152}$ and mainstreaming a norm of climate action in the contracting parties.

Part of the contribution of this article, in applying a legal pluralist analysis, has been to foreground the diversity of the elements which constitute the Energy Community as a hybrid legal space. The Energy Community can be seen to have drawn heavily on an existing 'international normative repertoire' of 'national legislation', 'multilateral negotiations', 'administrative decisions' and other available modalities. ${ }^{153}$ Moreover, the interactions between - and constraints upon - EnC actors have arguably produced additions to this 'repertoire', notably in the realms of transposition of laws and dispute management. However, in addition to facilitating 'transfers of social components such as economic products and capital ... between different societal contexts and different legal orders', ${ }^{154}$ instances of hybrid regulation such as the Energy Community can also be evaluated on their ability to transfer - or trigger changes in - norms. For the Energy Community, the

\footnotetext{
${ }^{150} \mathrm{~N}$ Affolder, 'Transnational Law as Unseen Law' in Zumbansen (n 37) 364

${ }^{151}$ Leal-Arcas et al (n 13) 353

${ }^{152}$ D Nelken, 'Defining and Using the Concept of Legal Culture' in E Örücü and D Nelken (eds), Comparative Law: A Handbook (Hart 2007) 111.

${ }^{153} \mathrm{~F}$ Snyder, 'The Origins of the "Nonmarket Economy": Ideas, Pluralism and Power in EC Anti-dumping Law About China' (2001) 7 European Law Journal 369, 420.

${ }^{154} \operatorname{Kjaer}$ (n 39).
}

challenge of embedding norms of climate action and environmental protection in contracting party practice will only grow as the 2030 Framework's more demanding requirements are added to the existing acquis.

An approach of legal pluralism also suggests the wisdom of acceptance of living with certain differences. As has been seen, the Energy Community is a hybrid legal space, not merely a receptacle for 'transplanted' law. The 2030 Framework in the Energy Community will be different to the 2030 Framework in the EU, and further tension between the particularities of EnC law and practice, and the homogeneity principle, can be expected. Nevertheless, only with targeted adaption of the 2030 Framework, with due attention to the contextual factors of each contracting party, will there be prospects of sufficient national implementation. Moreover, a more strategic commitment by EU institutions to contextual legal adaptation could unlock some of the Energy Community's latent potential to change the laws, practices and outlooks of contracting parties.

To achieve this will require significant efforts from all the stakeholders concerned, including ambitious proposals from the European Commission to strengthen both substantive EnC climate law and compliance procedures. The Energy Community remains a significant experiment in the expansion of EU law beyond EU frontiers. It is also an intriguing case study within a broader transnational landscape of 'hybrid and modular form in which the governance activities of states and a wide array of non-state actors are not neatly separated, but functionally overlapping. ${ }^{155}$ The dynamic of EnC Treaty implementation has always been of the Secretariat pushing the contracting parties to do more. The nascent climate acquis may suffer from greater resistance and capacity constraints than more familiar areas of energy law. As the EU strives for ambitious implementation of the 2030 framework, its near neighbours in the Energy Community stand at the junction of convergence or divergence. Ultimately, the EnC Secretariat will require greater support from the European Commission, but also from the other EU institutions and individual Member States, all of which have a stake in the Energy Community's success.

\section{ORCID}

Stephen Minas (iD https://orcid.org/0000-0001-7572-0123

\footnotetext{
${ }^{155} \mathrm{~A}$ Jordan et al, 'Governing Climate Change: The Promise and Limits of Polycentric Governance' in A Jordan et al (eds), Governing Climate Change: Polycentricity in Action? (Cambridge University Press 2018) 361.
} 
Stephen Minas (PhD) is assistant professor at the School of Transnational Law, Peking University, vice-chair of the UNFCCC Technology Executive Committee, senior research fellow at the Transnational Law Institute, King's College London and a member of IUCN's World Commission on Environmental Law. Stephen has worked on climate law and negotiations in various capacities and has published on the law and governance of energy and climate technology and finance, with particular focus on the interplay of international, European and national laws.

This article is written in a personal capacity. The views expressed in this article are personal to the author and do not necessarily represent the position of any institution. The author is grateful for the helpful and perceptive feedback of the special issue editors, the anonymous reviewer and the participants in the GOVTRAN workshop on 'Appraising the EU's 2030 Climate and Energy Policy Framework', especially the paper discussant, Dr Claire Dupont.
How to cite this article: Minas S. EU climate law sans frontières: The extension of the 2030 Framework to the Energy

Community contracting parties. RECIEL. 2020;29:177-190.

https://doi.org/10.1111/reel.12352 


\section{University Library}

\section{- M M N E R VA A gateway to Melbourne's research publications}

Minerva Access is the Institutional Repository of The University of Melbourne

Author/s:

Minas, $S$

Title:

EU climate lawsans frontieres: The extension of the 2030 Framework to the Energy Community contracting parties

Date:

2020-06-30

\section{Citation:}

Minas, S. (2020). EU climate lawsans frontieres: The extension of the 2030 Framework to the Energy Community contracting parties. REVIEW OF EUROPEAN COMPARATIVE \& INTERNATIONAL ENVIRONMENTAL LAW, 29 (2), pp.177-190. https://doi.org/10.1111/ reel.12352.

Persistent Link:

http://hdl.handle.net/11343/280516

License:

CC BY 